\title{
Materiaty
}

Klio. Czasopismo poświęcone dziejom Polski i powszechnym PL ISSN 1643-8191, t. 24 (1)/2013, s. 139-168

(c) (1) $\Theta$ DOI: $10.12775 /$ KLIO. 2013.006

\section{Katarzyna PĘKaCKa-FalKowska}

(Poznań)

\section{Gottfried Wilhelm Leibniz o sposobie udoskonalenia medycyny}

Niekiedy rano, gdy wciąż leżę w łóżku, do głowy przychodzi mi w ciągu zaledwie godziny tak wiele myśli, że ich dokładne spisanie zajmuje mi cały poranek, a niekiedy dzień i dłużej...

G.W. Leibniz*

W

1588 roku w Tragicznej historii Doktora Fausta Christopher Marlowe napisał: „ubi disinit philosophus, ibi incipit medicum”. Nieco ponad sto lat później, w 1696 roku, Gottfried Wilhelm Leibniz, który w wieku młodzieńczym tak jak Faust szukał kamienia filozoficznego ${ }^{2}$, zastanawiał się w liście do Guillaume’a Françoisa Antoine’a markiza de l'Hôpital: „Być

* Cyt. za: E. Bodemann, Die Leibniz-Handschrifte: der Königlichen Öffentlichen Bibliothek zu Hannover, 2. Aufl., Hildesheim 1996, s. 338.

${ }^{1}$ Ch. Marlowe, Tragiczna historia doktora Fausta, przeł. J. Kydryński, Kraków 1982, s. 8. Pl.: „Tam, gdzie kończy się filozof, tam zaczyna się lekarz”.

2 Zob. np.: Leibniz, Mysticism and Religion (International Archives of the History of Ideas / Archives internationales d'histoire des idées), ed. A. P. Coudert, R. H. Popkin, G. M. Weiner, Dordrecht 1998, passim. 
może spodobałoby się Bogu, gdyby lekarze filozofowali albo filozofowie leczyli?"’3. Jednakże w odróżnieniu od innych siedemnastowiecznych gigantów myśli - takich jak na przykład John Locke czy Kartezjusz Leibniz nie był lekarzem.

Fakt, że filozof nie otrzymał wykształcenia medycznego, nie zaważył jednak negatywnie na jego zainteresowaniu medycyną epoki ${ }^{4}$. Okresem szczególnie ożywionej refleksji Leibniza nad arte medica, w szczególności zaś nad jej umocowaniem instytucjonalnym były lata siedemdziesiąte XVII wieku, choć także w późniejszym okresie filozof chętnie podejmował w wielu pismach wspomnianą problematykę (wpisującą się zarówno w obszar zainteresowań filozofii naturalnej, jak i sztuki dobrego rządzenia).

Pod koniec lat sześćdziesiątych i w latach siedemdziesiątych powstały takie teksty, jak na przykład: De vera ratione reformandi rem literariam meditationes, für den Kufürsten von Mainz $(1668)^{5}$, Bedenken von Aufrichtung einer Academie oder Societät in Teutschland zu Aufnehmen der Künste und Wissenschaften $(1669 / 1671)^{6}$, Societät Gottgefällig $(1671)^{7}$ i Grundriß eines Bedenckens von Aufrichtung einer Societät in Teütschland $z u$ auffnehmen der Künste und Wißenschafften $(1671)^{8}$, a więc pierwsze

${ }^{3}$ Cyt. za: J. Smith, Divine Machines: Leibniz and the Sciences of Life, PrincetonOxford 2011, s. 43.

${ }^{4}$ Więcej na ten temat zob. np.: H. Burkhardt, Leibniz und die Medizin, „SandozBulletin” 1972, vol. 27, s. 36-46; F. Hartmann, Gottfried Wilhelm Leibniz und seine Anforderungen an eine Medizin der Aufklärung: Festvortrag zum 40-jährigen Bestehen der Medizinischen Gesellschaft Mainz am 4. Dezember 1991, Wiesbaden 1993; M. D. Grmek, Leibniz et la médecine pratique, [w:] Leibniz, 1646-1716, aspects de l'homme et de l'oeuvre [Journées Leibniz, organisées au Centre International de Synthèse les 28, 29 et 30 mai 1966], Paris 1968, s. 145-177; K. Pękacka-Falkowska, Leibniz i instytucjonalizacja opieki medycznej albo o trzech tekstach z 1681, 1694 i 1701 roku, „Klio” 2010, t. 15, s. 125-131.

5 Tekst opublikowano w: Leibniz und seine Akademie: Ausgewählte Quellen zur Geschichte Berliner Sozietät der Wissenschaften 1697-1716, hrsg. von H.-S. Brather, Berlin 1993, s. 53-56.

${ }^{6}$ G. W. Leibniz, Sämtliche Schriften und Briefe, R. 4: Politische Schriften, Bd. 1, Berlin 1983, s. 543-552.

7 Ibidem, s. 561 i nast.

${ }^{8}$ Ibidem, s. 530-543. Por.: G. W. Leibniz, Politische Schriften, Bd. 2, hrsg. von H. H. Holz, Frankfurt 1967, s. 32-47. 
leibnizjańskie projekty towarzystw naukowych, w których dwudziestokilkulatek postulował objęcie medycyny patronatem książęcym i włączenie jej w administracyjne struktury państwowe ${ }^{9}$. Mniej więcej w tym samym czasie Leibniz przygotował również Directiones ad rem medicam pertinentes - rozbudowaną „listę życzeń” ${ }^{10}$, które dotyczyły kwestii teoretycznych, praktycznych i instytucjonalnych związanych z ówczesną sztuką leczenia. Należy przy tym pamiętać, że zarysowana we wszystkich wymienionych pismach problematyka medyczna powracała także $w$ innych pracach filozofa, w których była rozbudowywana lub modyfikowana w zależności od aktualnych zainteresowań czy dążeń autora. I tak, medycyna wysunęła się na plan pierwszy między innymi w projektach Societas sive ordo caritatis $(1678)^{11}$ i Societas Theophilorum ad celebrandas laudes Deiopponenda gliscendi per orbem atheismo $(1678)^{12}$, w których filozof postulował zapewnienie bezpłatnej opieki lekarskiej dla ludzi ubogich, w szkicu edyktu z 1701 roku związanego z pracami nad reorganizacją Królewskiego Pruskiego Towarzystwa Nauk w Berlinie, dla którego mieli pisać sprawozdania medyczne najznamienitsi lekarze z całej Europy, czy na przykład w tekstach z 1716 roku obejmujących plany wyłączenia teatru anatomicznego z berlińskiego Obserwatorium i powołania sekcji chirurgicznej przy wspomnianym już towarzystwie naukowym ${ }^{13}$. Zagadnienia (około) medyczne pojawiały się także - rzecz jasna - w innych tekstach Leibniza $\mathrm{i}$ to nie tylko w jego korespondencji prywatnej czy urzędowej ${ }^{14}$, drobnych

9 Zob. np.: F. Hartmann, W. Hense, M. Krüger, Die Stellung der Medizin in Leibniz' Entwürfen für Sozietäten, „Studia Leibnitiana” 1990, Sonderheft 16: Leibniz in Berlin, s. 241-252.

${ }^{10}$ Określenie zapożyczone od J. Smitha i V. Keller. Zob.: J. Smith, op. cit., s. 33.

${ }^{11}$ G. W. Leibniz, Sämtliche Schriften und Briefe, R. 4: Politische Schriften, Bd. 3, Berlin 1983, s. 847-849.

12 Ibidem, s. 849-852.

${ }^{13}$ Cyt. za: H. Klenner, Leibnizens Denkschriften vom 26. März 1700 „eine societatem scientiarum et artium zu fundiren” und das Reglement der königlich-preußischen "Societät der Wißenschaften alhier” vom 3. Juni 1710, „Sitzungsberichte der Leibniz-Sozietät der Wissenschaften zu Berlin” 2011, H. 110, s. 28, 83; A. Harnack, Geschichte der KöniglichPreußischen Akademie der Wissenschaften, Bd. 1, Berlin 1900, s. 212.

${ }_{14}$ Zob. np.: G. W. Leibniz, Sämtliche Schriften und Briefe, R. 1: Allgemeiner, politischer und historischer Briefwechsel, Bd. 8, Berlin 1970, passim; K. F. Marx, G. W. Leibniz in 
szkicach czy projektach ${ }^{15}$, lecz także w większych rozprawach filozoficznych, acz w przypadku tych ostatnich ars medica nigdy nie stała się ich najważniejszym tematem ${ }^{16}$.

Dla Leibniza - tak jak dla wielu innych siedemnastowiecznych myślicieli - medycyna była nauką o znaczeniu podstawowym. Nie dziwi więc, że $\mathrm{w}$ jednym z listów do jezuity Joachima Bouveta filozof stwierdził explicite:

\begin{abstract}
Medycyna jest jedną z najważniejszych nauk (przyrodniczych). Albowiem tak jak teologia jest najwyższym szczytem poznania rzeczy przynależnych duchowi - i zamyka w sobie naukę o moralności i sztuce rządzenia - tak, można rzec, medycyna jest najwyższym szczytem i jakby najdojrzalszym owocem poznania ciała ludzkiego. Przy czym fizyka w ogólności, a medycyna w szczególności swój cel ostateczny znajdują w chwale Boga i szczęściu człowieka: ponieważ zachowując [zdrowie], zapewniają narzędzia do pracy na chwałę Pana ${ }^{17}$.
\end{abstract}

Już ten krótki cytat pokazuje, że Leibniz pojmował zdrowie - zgodnie z wykładnią luterańską - jako to, co dane (niem. Gabe) i zarazem zadane (niem. Aufgabe), oraz coś, co przynależy do porządku ducha i porządku cia$\mathrm{ta}^{18}$. Stąd też wszystko, co „przyczynia[ło] się do [jego] konserwacji oraz zachowania ducha i dobrego imienia, [filozof] uważa[1] za niezbędne" ${ }^{19}$. Z tej

seiner Beziehung zur Arzneiwissenschaft, „Abhandlungen der Königlichen Gesellschaft der Wissenschaften zu Göttingen” 1860, Bd. 8, s.105 i nast.

${ }^{15}$ Zob. np. teksty Leibniza opublikowane w „Klio. Czasopiśmie poświęconym dziejom Polski i powszechnym", numer specjalny: Spoteczna historia medycyny w dobie oświecenia, 2010, t. 15, s. 133-150.

${ }^{16}$ Zob. np.: G. W. Leibniz, Nowe rozważania dotyczace rozumu ludzkiego, tłum. I. Dąbska, Kąty 2001 (kwestie działania wyobraźni matki, potworkowatości itp.); idem, Protogaea, trans. and ed. C. Cohen, A. Wakefield, Chicago 2008 (problem eksperymentu medycznego, zastosowanie lecznicze zęba żarłacza kopalnego itp.).

${ }^{17}$ Otium Hanoveranum: sive miscellanea ex ore et schedis G. Guil. Leibnitii, descr. J. F. Fellerus, Lipsiae 1718, Nr. LXIII: Au Pere Bouvet, á Paris. 1697, s. 115. Por.: Gothofredi Guillelmi Leibnitii Opera omnia: nunc primum collecta, in classes distributa, praefationibus et indicibus exornata, ed. L. Dutens, t. 2, p. 1, Geneva 1768, s. 262.

${ }^{18}$ G. W. Leibniz, Agenda, respectu Dei, principis aliorum, [w:] Die Werke von Leibniz, R. 1: Historisch-politische und staatswissenschaftliche Schriften, Bd. 4, hrsg. von O. Klopp, Hannover 1865, s. xxvii i nast.

${ }^{19}$ Ibidem, s. xxviii. 
przyczyny instytucje, które promowały i wspierały rozwój wspomnianych obszarów życia ludzkiego, należało otoczyć specjalną opieką państwową, gdyż tylko dzięki patronatowi królewskiemu / książęcemu mogły one rozwijać się harmonijnie i w konsekwencji pomagać osiągnąć każdemu człowiekowi prawdziwą szczęśliwość (niem. Heil) - i to nie tylko cielesną, lecz także społeczną i duchową ${ }^{20}$.

Liczne sposoby poprawy medycyny jako nauki i sztuki, która łączy teorię z praktyką, Leibniz przedstawił w prezentowanych dziś po raz pierwszy w polskim przekładzie Directiones ad rem mediciam pertinentes. Był to projekt wielkiej, wizjonerskiej reformy niezrealizowany za życia filozofa. Niektóre pomysły Leibniza urzeczywistniły się dopiero w dziewiętnastym stuleciu i utrwaliły się w praktyce codziennej przedstawicieli nauk medycznych w XX wieku.

${ }^{20}$ Więcej na temat leibnizjańskiego Heil zob.: K. Pękacka-Falkowska, Leibniz i instytucjonalizacja..., s. 127; M.-N. Dumas, Leibniz und die Medizin, „Studia Libnitiana” 1978, Sonderheft 7: Magia naturalis und die Entstehung der modernen Naturwissenschaften, s. 152 . 


\title{
Tekst źródłowy
}

\author{
GotTfried Wilhelm LeIBNIZ \\ [1671/1672]
}

\section{Zalecenia dotyczace medycyny*}

rzeba posiadać narzędzia do dokładnego badania uryny i pulsu, ponie-
waż te są ogólnymi znakami stanu człowieka.

* Podstawę przekładu stanowi wydanie przygotowane przez Berlin-Brandenburgische Akademie der Wissenschaften, które ukaże się niebawem w: G. W. Leibniz, Sämtliche Schriften und Briefe, R. 8: Naturwissenschaftliche, medizinische und technische Schriften, Bd. 2, Berlin 2013, Nr. 60 [w druku]. Po raz pierwszy edycję tekstu (różniącą się nieznacznie od edycji BBAW) opublikowano w: F. Hartmann, M. Krüger, Directiones ad rem medicam pertinentes. Ein Manuskript G. W. Leibnizens aus den Jahren $1671 / 72$ über die Medizin „Studia Leibnitiana” 1976, Bd. 8, s. 40-68. Interpretacje Directiones zawierają m.in.: G. Rath, Unbekannte medizinische Vorschläge aus den Leibnizarchiv, „Deutsche Medizinische Zeitschrift”, 1951, Jg. 76, s. 745-747; F. Hartmann, M. Krüger, Methoden ärztlicher Wissenschaft bei Leibniz, „Studia Leibnitiana”, 1973, Bd. 1, s. 235-247; Ch. Barthel, Medizinische Polizey und medizinische Aufklärung. Aspekte des öffentlichen Gesundheitsdiskurs im 18. Jahrhundert, Frankfurt 1989, s. 115-118; A. Trunk, An early concept of G. W. Leibniz regarding medicine, [w:] The Globaland the Local: The History of Science and the Cultural Integration of Europe. Proceedings of the 2nd ICESHS (Cracow, Poland, September 6-9, 2006), ed. M. Kokowski, dokument elektroniczny: http://www.2iceshs.cyfronet.pl/2ICESHS_Proceedings/Chapter_13/R-5_Trunk.pdf (data dostępu: 07.03.2013); J. Smith, Divine Machines. Leibniz and the Sciences of Life, PrincetonOxford 2011, s. 33-37; idem, Leibniz and Medicine, [w:] The Oxford Handbook of Leibniz, ed. M. R. Antognazza, Oxford 2013 [w druku]. 
W przypadku uryny nie ma nic lepszego niż dobry mikroskop ze szklaną soczewką ${ }^{1}$, ponieważ pozwoli on odkryć tysiąc rzeczy, których inaczej nie da się znaleźć w urynie - i w krótkim czasie dojdzie się do takich reguł, które przewyższą wszystkie wcześniejsze.

W taki sam sposób będzie można użyć go do przebadania upuszczonej krwi. Jak zauważył Galen, wyczucie pulsu jest niemożliwe, dopóki dłonie najlichszego z medyków nie osiągną doskonałości w wyczuwaniu wszelkich różnic ${ }^{2}$. Dlatego warto wprowadzić w życie wielkie myśli, które słynny Marcus Marci przelał na papier w Sphygmica ${ }^{3}$.

Urynę i krew można by także uważnie destylować, filtrować, poddawać próbom przy użyciu ognia lub bez niego oraz na inne sposoby, w szczególności wtedy, gdy istnieją jakieś wątpliwości.

W ten sam sposób co z krwią i uryną, a nawet więcej aniżeli z krwią, można by postępować ze śliną; ją nawet pierwej poddawać badaniu, łatwiej ją bowiem pozyskać.

I wierzę, że ze śliny, tak jak z uryny można wiele wywnioskować o ludzkiej konstytucji, i że z analizy (łac. anatomie) śliny można wywieść przyczyny, dlaczego człowiek je chętnie to, a nie je tamtego. Ślinę można by klarować, rozpuszczać w czystej wodzie studziennej itp., tak też [można by czynić] z uryną; ślinę i mocz można by skrystalizować, dodać doń rozmaite solventia $a^{4}$ oraz reagentia itp., w ten sposób pojawią się barwy, na podstawie których będzie można orzekać o konstytucji człowieka.

${ }^{1} \mathrm{Nt}$. początków anatomii mikroskopowej zob. np.: Historia medycyny, red. T. Brzeziński, Warszawa 2000, s. 130 i nast.

2 C. G. Pergameni, De praecognitione libellus, Leonardo Jacchino interprete, eiusdem explanationes in eundem Galeni libellum, Lyon 1540; idem, On prognosis [De praecognitione], [w:] Corpus Medicorum Graecorum, ed. V. Nutton, Berlin 1979, s. 3 i nast.

3 Johannes Marcus Marci (1595-1667), zwany również Hipokratesem z Pragi, był profesorem medycyny na Uniwersytecie Karola w drugiej poł. XVII w. Stworzył matematyczną metodę badania tętna poprzez porównywanie go z częstotliwością drgań wahadła. Por.: I. M. Marci, De proportione motus, seu regula sphygmica ad celeritatem et tarditatem pulsuum etc., Pragae 1639; K. E. Soorensen, A Study of the De proportione motus by Marcus Marci de Kronland, „Centaurus” 1977, vol. 21, iss. 3-4, s. 246-277.

${ }^{4}$ Solventia - środki rozpuszczające. Zob.: Grosses vollständiges Universal-Lexicon Aller Wissenschafften und Künste, Bd. 38: Sk-Spie, Leipzig 1743, s. 338; ibidem, Bd. 18: Lo-Lz, Leipzig 1738, s. 115 (dalej cyt. jako Zedler). Źródło internetowe: www.zedler-lexikon.de (data dostępu: 07.03.2013).

${ }^{5}$ Reagentia - odczynniki. Zob.: Zedler, Bd. 30, s. 611. 
Następnie, przy pomocy medicinae staticae, należy zaszczepić wśród ludzi nawyk badania za pomocą pytań, tj. zaprowadzić inkwizycję generalną̧, co po raz pierwszy ujęto w reguły dzięki Santorio i jego trzydziestoletnim doświadczeniom? ${ }^{7}$. [Całą wiedzę, którą zyska się w ten sposób,] należy następnie zebrać, zapisać i dostosować do wszystkich poszczególnych przypadków. Można by także wprowadzić eksperymenty z zakresu medicae elasticae ${ }^{8}$, badające, jak zwiększają się lub zmniejszają siły człowieka; [takich eksperymentów] należy dokonywać w trakcie napinania łuku albo rzucania w dal, najlepiej w trakcie jakiejś długotrwałej czynności, jak chodzenie, noszenie itp., najlepiej w czasie jakiegoś wysiłku.

Do obserwacji pulsu należy obserwacja ciepła i zimna dłoni dzięki dokładnemu, odpowiednio ulepszonemu termometrowi, albowiem wielu ludzi ma z natury dłonie zimne, wielu zaś ciepłe, w zależności od swej konstytucji.

${ }^{6}$ Według Pierer's Universal-Lexikon (Bd. 7, Altenburg 1859, s. 142) Generalinquisition to pierwsza część procesu kryminalnego - od otrzymania pierwszej wiadomości na temat popełnionego przestępstwa aż do momentu, w którym sędzia śledczy wystąpi przeciw określonej osobie jako domniemanemu sprawcy (wtedy następuje druga część procesu, tzw. Specialinquisition). Celem Generalinquisition jest stwierdzenie obiektywnego sprawstwa zbrodni i zebranie materiału dowodowego, który obciąża określoną osobę jako domniemanego sprawcę. Według Herders Conversations-Lexikon (Bd. 3, Freiburg im Breisgau 1855, s. 47-48) Generalinquisition to śledztwo wstępne.

7 Santorio Santorio (1561-1636) był jatrofizykiem, profesorem medycyny w Wenecji i Padwie. Uczony konstruował termometry, higrometry, wagi itp. Szczególnie istotne były jego wieloletnie badania nad masą ciała ludzkiego w różnych porach dnia, przed zjedzeniem i po zjedzeniu posiłku, przed oddaniem stolca i moczu oraz po ich oddaniu itd. Por.: idem, De statica medicina aphorismorum sectionibus septem comprehensa etc., Venezia 1614; Historia medycyny..., op. cit., s. 124 i nast.

${ }^{8}$ Medica elastica - według Leibniza dział medycyny badający elastyczność mięśni, czyli ich kurczliwość (np. siłę i czas skurczu). Co istotne, mięśnie wykazują fizyczne cechy ciał martwych: po pierwsze, zdolność do reagowania odkształceniem na działającą siłę (ale niezgodnie z prawem Hooka, tzn. równy ciężar dodany nie powoduje jednakowego przyrostu długości) i zdolność do powrotu do pierwotnej formy po odjęciu siły rozciągającej, oraz - po drugie - szczególne właściwości elastyczne (pod wpływem siły rozciągającej lub pobudzenia nerwowego mogą zmieniać swoje napięcie, nie zmieniając długości). 
Przy tym termometr musi zostać poddany kalibracji zgodnie z radami Pana Eschinardiego', jak i stosownie do twierdzeń ogłoszonych w Anglii na temat termometru okragłego, co przedstawia Historia Societatis ${ }^{10}$.

Dalej, można by wprowadzić badania na ludziach podczas kąpieli, w ten sposób, że przebada się i podda analizie to, co się od nich oddzieli.

Tak też można przebadać oddech wtedy, gdy uwalnia się go (łac. reductio) $\mathrm{z}$ ciała $^{11}$.

Każdy człowiek musi baczyć sam na siebie ze względu na poty. Pot można zebrać i zbadać pod kątem stopnia jego zasolenia itp.

Trzeba mieć w państwie określonych ludzi, którzy obeznani z zapachem, dotykiem, smakiem itp. osiągnęli w nich najwyższą perfekcję. Dzięki nim będzie można zbadać wszelkie rzeczy wątpliwe.

Każdy urząd powinien utrzymywać uczciwego medyka, chirurga, aptekarza i wielu innych ludzi tego typu.

Kucharz powinien perfekcyjnie odróżniać rzeczy po smaku i zapachu; przy czym powinno się go z tego egzaminować.

${ }^{9}$ Francesco Eschinardi (1623-1703) był jezuitą, nauczał matematyki w Collegio Romano. Leibniz nawiązuje tu do jego tekstu: Difetti di termometri, „Giornale de'Letterati”, 27 lutego 1670, s. 22 (przyp.), przy czym filozof pisał o nim także do Ottona von Gurickego: „Ich bin neulich ohngefähr im Römischen Journal über eine Epistel eines mathematici nahmens Eschinardi kommen, welche vorgibt, dass die thermometra nicht in gleiche, sondern einander ungleiche Theile muessen abgetheilt werden, weil sie nicht motu uniformi sondern accelerato steigen und wuechsen. Es ist bekand dass ohne das die thermometri sehr ungewiss, indem gradus raritatis in Aaere nicht allein von Wärme und Kälte, sondern auch trockene und Feuchte variirt wird" (cyt. za: R. Muschall, Zur Vorgeschichte der technische Normung, Berlin-Köln 1992, s. 46).

${ }_{10}$ T. Sprat, The History of the Institution, Design, and progress of the Royal Society of London for the Advancement of Experimental Philosophy, London 1667, s. 313: „therefore he [...] invited a Circular Thermometer, in which the liquor occasions no fallacy, but remains alwayes in one height moving the whole Instrument, like a Wheel on its Axis".

${ }^{11}$ L. Bellini, Consideratio nova de natura et modo respirationi, „Miscellanea Curiosa Medico-Physica Academiae Naturae Curiosorum" 1671, A. 2, s. 135-139. Por.: Caroli Drelincurtii... Dissertatio anatom.practica de lienosis, apud J. A. Langerack, Lugduni Batavorum 1711 (Ed. 3., prioribus longe emendatior, accedit D. Laurentii Bellini Consideratio nova de natura \& modo respirationis). 
Balwierz powinien mieć doskonały dotyk. Trzeba by mieć ludzi, którzy przez dotyk mogą dojść do tego, do czego doszedł ślepy u Boyle’a $\mathrm{w}$ ten oto sposób wszystko jest możliwe ${ }^{12}$.

Także z jasności, siły, czystości itp. mowy człowieka można wyciągnąć wnioski medyczne.

Trzeba stosować wszystkie już opracowane eksperymenty i posługiwać się [dokonanymi już] obserwacjami medyczno-fizycznymi.

Trzeba je wszystkie zebrać i uporządkować według stopnia [ich] prawdopodobieństwa.

Wówczas trzeba będzie je wszystkie jak najszybciej wypróbować.

Niektóre można wypróbować wtedy, gdy się tego chce, i zawsze musi zajść to samo.

Niektóre, np. środki lecznicze przeciwko pewnym chorobom, można wypróbować tylko wtedy, gdy nadarzy się ku temu odpowiednia okazja. I dlatego trzeba sprawić, aby w każdej miejscowości powstał katalog tamtejszych pacjentów wraz ze wszystkimi okolicznościami i szczegółami [dotyczącymi ich chorób].

Badania można prowadzić tylko wtedy, gdy opierają się one na wskazówkach [potrzebnych] do wykonania próby. Lecz gdyby wytyczne były nieścisłe, wówczas pacjent byłby zgubiony ${ }^{13}$.

Trzeba wszędzie gromadzić ludzi i im ogłaszać, że każdy, kto zna pożyteczne długo- lub krótkoterminowe kuracje, ma o nich opowiedzieć, wskazując jednocześnie na czynniki, od których są one uzależnione; i że należą mu się za to szacunek i liczne pochwały. Lekarza urzędowego ze względu na to, że zgromadzi tak wiele przystojnych rzeczy, także należy obdarzyć estymą.

${ }^{12}$ Chodzi o historię ślepego Duńczyka, który dzięki dotykowi potrafił odróżnić barwę identycznych pod innymi względami kawałków materiału. Stąd Robert Boyle postawił hipotezę, że cząsteczki, które tworzą farby, są „a-sferyczne”, np. gładkie albo szorstkie, w zależności od koloru. Inna hipoteza filozofa brzmiała następująco: wspomniany ślepiec miał tak wyostrzony i „subtelny” węch, że farby rozróżniał po ich zapachu. Zob.: R. Boyle, Experiments and conciderations touching colours, London 1662, s. 41-49.

13 Por.: L. Dutens, Gothofredi Guillelmi Leibnitii... Opera omnia, vol. 2, p. 2, Geneva 1768, s. 118. 
Każdy lekarz i chemik powinien stale prowadzić dziennik swoich badań.

Trzeba zebrać wszystko, co o simplicitach ${ }^{14}$ mówią stare baby tudzież straganiarze.

Wszyscy pacjenci, którzy umarli w szpitalu, powinni zostać poddani sekcji.

Byłoby dobrze, gdyby większość ludzi była poddawana sekcji.

Wszystkie sekcje powinny odbywać się na różne sposoby, co opisał w książce Anatomia cerebri Monsieur Stenonis ${ }^{15}$.

W przypadku ludzi poddawanych sekcji trzeba dowiedzieć się jak najwięcej o [ich] historii naturalnej i wtedy przebadać ich wszystkie humory ${ }^{16}$ itp., sok trzustkowy ${ }^{17}$, żółć itp., to, czy ślina jest raczej kwaśna, czy raczej słona itp., jakiej barwy będzie żółć albo poszczególne organy po zastosowaniu ligni Nephretici ${ }^{18}$ itp.

W trakcie sekcji należy wyróżnić wszystkie najdrobniejsze szczegóły, zbadać wszystkie przewody i pasaże po wpuszczeniu do nich płynu barwiącego, użyć wszelkiego rodzaju ligatur ${ }^{19}$.

Trzeba wynaleźć sposób, w jaki można powodować krzepnięcie krwi - zgodnie z metodą Bilsiego ${ }^{20}$ - żeby nie utrudnić sekcji.

14 Simplicita - leki proste oraz surowce aptekarskie. Mogły pochodzić z królestwa roślin (vegetalia), zwierząt (animalia) oraz minerałów (mineralia).

15 Niels Stensen (1638-1686) - duński anatom i badacz historii naturalnej, jeden z twórców stratografii. Zob.: idem, Dissertatio de cerebri anatome, Leyden 1676, s. 51-58 (tłumaczenie angielskie: Nicolaus Steno's Lecture on the Anatomy of the Brain, transl. by G. Scherz, Copenhagen 1965; tłumaczenie francuskie: Discours sur l'anatomie du cerveau, présenté et annoté par R. Andrault, Paris 2009).

${ }^{16}$ Czyli cztery podstawowe płyny ustrojowe w medycynie humoralnej (krew, flegma, żółć i czarna żółć).

17 O badaniach „soku trzustkowego” zob. np.: L. Kooijmans, Niebezpieczna wiedza. Wizje i lęki w czasach Jana Swammerdama, Warszawa 2010, s. 105.

18 Lignum nephreticum (nephridicum), santalum coeruleum, niem. Gries-Holz, fr. Bois néphrétique - błękitny sandałowiec, substancja barwiąca. Zob.: Zedler, Bd. 11, s. 472; Pierer's Universal-Lexikon, Bd. 7, Altenburg 1859, s. 648.

${ }^{19}$ Ligatura - podwiązka chirurgiczna, służąca do podwiązywania naczyń krwionośnych w trakcie zabiegu.

${ }^{20}$ Chodzi o metodę balsamowania zwłok opracowaną przez duńskiego lekarza i anatoma Luisa de Bilsa (1624-1670). I chociaż metody swej sam anatom nigdy nie upublicz- 
Trzeba znaleźć płyn, który wyżre mięso, lecz nie naruszy żadnych przewodów, dzięki czemu będzie można wszystko dokładnie przebadać.

Trzeba obchodzić się z ciałem ludzkim wnikliwie, z uwagą na wszystko, co istotne. Cały czas mieć przed sobą, by tak rzec, żywe anatomi [tj. żywy model]. Byłoby to o wiele lepsze niż rysunki [anatomiczne] z Kopenhagi czy Helmstedt.

Trzeba sprawdzić, jak szybko wypijane płyny przedostają się do pęcherza moczowego, co można zbadać dzięki piciu kwaśnej wody ${ }^{21}$, i w jaki sposób ołowiane kule [tj. pociski] opisane w „Engl. Transact.” mogą przejść przez cewkęer.

Trzeba przedłożyć wszystkim medykom dokładne pytania, zgodnie z którymi powinni badać swoich pacjentów.

Po tym, jak się je opublikuje, każdy roztropny człowiek będzie mógł poddać sam siebie badaniu i zapisać swą historię naturalną.

Aby przebadać naturę i ruch gazu trawiennego, trzeba by wtłoczyć powietrze do jelit albo je z nich wytłoczyć. Trzeba nakazać uniwersytetom i dociekliwym medykom przygotowanie specjalnych projektów [tj. kwestionariuszy] pytań ogólnych.

Aby dowiedzieć się, czy znaki na ręku tudzież w innych [miejscach ciała] mają jakąś siłę, trzeba by odwzorować wiele dłoni ludzi, których znamy. Będzie to łatwe, jeśli pociągniemy im dłonie płynem, który wyraźnie odtworzy to, co zostało zapisane w liniach. Zobacz Mey[ensa] Chiromantia medica²3.

Trzeba także dowiedzieć się i przebadać, jaki co ma związek z astrologią oraz zasadami ptolemejskimi ${ }^{24}$.

nił w pracy drukowanej, to jednak cieszyła się ona wielką popularnością wśród współczesnych. Por.: B. Wittenbergius, La nouvelle dissection sans effusion de sang, et l'embaumement de Monsr. Louys de Bils, Bruges 1675; L. Kooijmans, op. cit., passim.

${ }^{21}$ Acidola, cidula - kwaśna (tj. szczawa) woda lecznicza. Por.: Zedler, Suppl. 1, s. 192.

${ }^{22}$ N. Fairfax, Account of a Bullet Voided by Urin, „Transactiones Philosophicae Societatis Regiae Londinensis" 1668, vol. 3, s. 803-805.

${ }^{23} \mathrm{Ph}$. Meyens von Coburg in Franckenlandt, Chiromantia medica. Mitt einem Anhang von den zeichen auff den Nägeln der Finger. Nebens einem Tractätlein Von der Physiognomia Medica, Haag 1667.

${ }^{24}$ Claudii Ptolemaei Opera Quae Exstant Omnia, vol. 3, fasc. 1: Apotelesmatica (Bibliotheca scriptorum Graecorum et Romanorum Teubneriana), hrsg. von W. Huebner, 
Trzeba przedłożyć ludziom zasady, jak mają postępować w jedzeniu i piciu. Powinni jeść wszystko drobno posiekane.

Trzeba wypróbować u wszystkich typów ludzi określone diety, na przykład trzeba dysponować ludźmi, których poi się jedynie mlekiem. Innych należy poić wyłącznie ciepłymi płynami, trzeci zaś mają jeść tylko to, co nieżywe itp.; trzeba mieć kilka [osób] do każdej [diety].

Trzeba zwrócić uwagę na kondycję danej osoby, na stan, z którego się wywodzi, na jej sposób życia, na jej dietę i na wszystko inne; i na wywoływane [przez te rzeczy] następstwa.

Trzeba przebadać, czy odżywianie się zwierzętami, które karmiono w określony sposób - ziołami, [mięsem innych] zwierząt itp. - będzie pożyteczne dla człowieka ${ }^{25}$.

Trzeba wypróbować na ludziach pewne środki, dzięki którym będą oni mogli we właściwy sposób się zestarzeć - i stąd wywieść model [postępowania] dla innych.

Trzeba za Panem Charasem szukać naturalnych przyczyn śmierci, aby w ten sposób znaleźć sposób przedłużania życia ${ }^{26}$.

Trzeba jak najdokładniej przebadać ludzi pod kątem tego, co chętnie jedzą i co im pachnie, i odwrotnie, oraz ze względu na stopień upodobania do pewnych rzeczy (łac. delectatio) ${ }^{27}$. Dlatego także trzeba zwrócić uwagę, jakimi tonami muzycznymi każdy [z nich] się delektuje, jak choćby

B. G. Teubner, Stutgardiae 1998. Na temat wiary w nauki Ptolemeusza, zob.: Historia medycyny..., op. cit., s. 104.

${ }_{25}$ Nawiązanie do funkcjonującego wśród siedemnastowiecznych medyków przekonania, że zwierzęta przejmują w siebie właściwości spożywanych pokarmów. Dotyczyło to przede wszystkim wiary w moc leczniczą bezoarów - kulistych tworów powstających w żołądkach zwierząt przeżuwających. Zob. np.: K. Pękacka-Falkowska, Profilaktyka przeciwdżumowa $w$ nowożytnym Toruniu na przyktadzie dziatań administracyjnych i leczenia, Toruń 2009, s. 137-140.

${ }^{26}$ M. Charas, Nouvelles experiénces sur la vipère, où l'on verra une description exacte de toutes ses parties, la source de son venin, ses divers effets et les remèdes exquis que les artistes peuvent tirer de la vipère, tant pour la guérison de ses morsures que pour celle de plusieurs autres maladies, Paris 1669 [źródło elektroniczne: http://gallica.bnf.fr/ark:/12148/bpt6k57424s]. Moyse Charas propagował spożywanie mięsa żmii jako środek przedłużania życia.

27 Delectatio - podrażnienia i przyjemności zarazem. 
w przypadku tych, których ukąsiły tarantule ${ }^{28}$. Tak samo, zgodnie z zasadą Platona, kiedy zmienia się muzyka, zmienia się też państwo ${ }^{29}$. Każdy musi zwracać uwagę na to, co mu sprawia największą przyjemność na świecie.

Trzeba doprowadzić rejestry zgonów do możliwie najwyższej perfekcji; i sporządzać je nie tylko w wielkich miastach ${ }^{30}$, lecz także na wsiach, a przy tym zapisywać dokładnie różnice w klimacie, [jakości] ziemi, [jakości] powietrza itp., z czego wyniknie wiele szlachetnych rzeczy ${ }^{31}$. Następnie należy nakazać określonym ludziom, aby ci na podstawie [takich rejestrów]

${ }^{28}$ Leibniz nawiązuje do zjawiska tarantyzmu - szału tańca, tanecznictwa. Nazwa ta wywodzi się od miasta w południowo-wschodnich Włoszech, Tarentu, który od XV do XVII w. był ośrodkiem manii tanecznej. W Tarencie wierzono bowiem, że na ukąszenie tarantuli najlepszą odtrutką jest tańczenie tarantelli. Zob. np.: W. Szumowski, Historia medycyny filozoficznie ujęta, Kęty 2008, s. 300 i nast.

${ }_{29}$ Zob.: Platon, Państwo, przełożył, wstępem i komentarzami opatrzył W. Witwicki, Kęty 2003, ks. IV, 424c, s. 122: „Aby nieraz ktoś nie sądził, że poeta mówi tutaj nie o nowych pieśniach, ale o nowym stylu śpiewania, i żeby tego nikt nie chwalił. Nie należy tego ani chwalić, ani czegoś podobnego u poety przyjmować. Trzeba się wystrzegać przełomów i nowości w muzyce, bo to w ogóle rzecz niebezpieczna. Nigdy nie zmienia się styl w muzyce bez przewrotu w zasadniczych prawach politycznych. Tak mówi Damon, a ja mu wierzę".

${ }^{30}$ Leibniz wierzył, że najłatwiej będzie wprowadzić to zamierzenie w życie we Francji ze względu na zaawansowaną organizację tamtejszej policji. Por.: idem, O sposobie udoskonalenia medycyny (1694), tłum. T. Falkowski, oprac. K. Pękacka-Falkowska, „Klio. Czasopismo poświęcone dziejom Polski i powszechnym” 2010, t. 15, s. 141-144. Miejskimi rejestrami zgonów par excellence były tabele wymieralności sporządzane przez Johna Graunta dla Londynu (Natural and Political Observations Mentioned in a Following Index and Made upon the Bills of Mortality, London 1662) i przez Edmunda Halleya dla Wrocławia (An estimate of the degrees of mortality of mankind drawn from tables of births and funerals in the city of Breslau with an attempt to ascertain the price of annuities upon lives, "Philosophical Transactions of the Royal Society of London” 1693, vol. 17, s. 596-610; Some further considerations of the Breslau Bills of Mortality, „Philosophical Transactions of the Royal Society of London” 1693, vol. 17, s. 654-656).

${ }^{31}$ Nawiązanie do neohipokratejskiej koncepcji dietetycznej i sex res non naturales oraz teorii konstytucji epidemicznej Thomasa Sydenhama. Por.: G. W. Leibniz, Propozycja utworzenia urzędu zdrowia (1680), tłum. i oprac. K. Pękacka-Falkowska, „Klio. Czasopismo poświęcone dziejom Polski i powszechnym” 2010, t. 15, s. 133-139; idem, Podsumowanie dotyczące obserwacji medycznych, które należy nieustannie podejmować $i$ kontynuować (zima 1701), tłum. i oprac. K. Pękacka-Falkowska, ibidem, s. 145-150. 
wyciągali wnioski ogólne [opierając się na metodzie indukcji] oraz prowadzili [dalsze] obserwacje.

Trzeba zwrócić uwagę na wpływy astrologiczne (łac. effectus Astrologicus): czy na przykład prawdą jest to, co się mówi, że jeśli kobieta porodzi w trakcie zaciemnienia [słońca], to zarówno ona, jak i nowo narodzone dziecko umrą, [trzeba sprawdzić także] inne przekazy tego typu.

Trzeba także zbadać, co zasady zawarte w kalendarzach mówią o związku między stosowaniem kąpieli, stawianiem baniek i upustem krwi a znakami niebieskimi i [fazami] księżyca, i skonfrontować to z tym, co napisali Kepler, Campanella, Trew $^{32}$ i inni uczeni.

Trzeba zebrać wszystkie simplicita z całego świata i zaczacć je uprawiać także w naszych stronach, co niewątpliwie umożliwi ich zbadanie.

Badanie simplicitów musi odbywać się w taki sposób, że najpierw sprawdzimy ich właściwości naszymi zmysłami i w przypadku każdej z nich określimy - na ile to możliwe - jej stopień. Następnie musimy tak dalece, jak to tylko możliwe, przebadać je per se, przez zgniatanie, przesączanie itp., destylację w wodzie tudzież ogniu, a następnie łączenie z solventibus, reagentibus. A potem - w ten sam sposób - należy zapisać właściwości wszystkich połączeńn ${ }^{33}$ i ich stopień.

Szczególnie interesującą pracą będzie przebadanie barw wszystkich rzeczy po użyciu kamienia lidyjskiego ${ }^{34}$, ligni Nephretici itd.

Co się zaś tyczy smaku, trzeba wymyślić nade wszystko sposób i środek [jego badania].

Musielibyśmy sprawdzić, czy wydzieliny menstruacyjne są w całości słodkie, kwaśne, słone itp., i w ten sposób określić także stopień [danej właściwości].

32 Abdias Trew (1597-1669) - niemiecki teolog, matematyk i astronom, autor m.in. Astrologia Medica. Quatuor Disputationibus Comprehensa, dzieła wydanego w 1660 roku w Hadze.

33 Połączenia simplicitów to leki złożone (compositia).

${ }^{34}$ Lydus lapis, niem. Probier-Stein - kamień probierczy. Zob.: Zedler, Bd. 18, s. 763. 
Trzeba także zwrócić uwagę, czy daną rzecz można uznać za wiarygodną ze względu na jej sygnaturę ${ }^{35}$, a tam, gdzie okaże się ona prawdziwa, czy będzie to wyraźny dowód [boskiej] Opatrzności.

Na zwierzętach - martwych i żywych - trzeba przeprowadzać liczne sekcje oraz wiwisekcje.

Trzeba przykładać większą niźli do tej pory uwagę do chorób zwierzęcych i skoro, jak rzekł Steno, całej współczesnej anatomii nauczyliśmy się od zwierząt, tak samo moglibyśmy się [od nich] nauczyć całej patologii, gdyż możemy je rozcinać oraz badać w dowolnym czasie i w dowolny sposób. I państwo płaciłoby za poszczególne zwierzęta, oddane dla dobra ogółu i wspólnego pożytku ${ }^{36}$.

W zasadzie kierujemy uwagę tylko na choroby koni, natomiast niemal wcale nie zwracamy jej na choroby innych zwierząt.

Na zwierzętach - w szczególności wtedy, kiedy rozpoznalibyśmy lepiej ich choroby - moglibyśmy także bez trudu i obaw wypróbowywać środki lecznicze. Na zwierzętach możemy prowadzić próby z lekami, gdy tylko zechcemy - i na tej podstawie budować analogie do ludzi; natomiast nie możemy tego czynić na ludziach.

Trzeba wprowadzić generalne wizytacje aptek i w ich trakcie ani nie zapomnieć o tym, co przeciw aptekarzom napisał Bartholin ${ }^{37}$, ani tego, co ostatnio wynikło z toczonych w Anglii dyskusji między medykami a aptekarzami $^{38}$.

35 Leibniz nawiązuje tu do paracelsiańskiej nauki o sygnaturach, czyli znakach zewnętrznych.

36 Niels Stensen, op. cit.

37 Nawiązanie do książki Sebastiéna Colina opublikowanej pod pseudonimem Benacio, którą przetłumaczył na łacinę Thomas Bartholin. Zob.: L. Benacio, Declaratio fraudum et errorum apud pharmacopoeos comissorum, Francofurti 1667.

${ }^{38} \mathrm{Na}$ temat sporu między angielskimi medykami i aptekarzami zob. np.: Ch. Merret, Short view of the frauds, and abuses committed by apothecaries: as well in relation to patients, as physicians, and of the only remedy thereof by physicians making their own medicines, London 1669; H. Stubbe, Lex talionis, London 1670; Ch. Merret, A short reply, London 1670; H. Stubbe, Medice cura teipsum!, London 1671. 
Trzeba dokładnie obserwować, po jakim czasie od wypicia płynu następuje oddanie moczu i od spożycia posiłku - wypróżnienie, co u jednego człowieka następuje wcześniej niż u drugiego.

Powinno się także zbadać, jak dalece można ufać bodźcom naturalnym i wywołanym sztucznie, jak wtedy, gdy natura powoduje wymioty przez krótkie impulsy związane z nudnościami albo otwarcie [tj. pęknięcie] żył przez nadmiar krwi, która się w nich znajduje. Podobnie [trzeba zbadać,] jak dalece [można] podążać za naturalnym dążeniem (łac. apetit) w spożywaniu tego i owego, w spaniu itp.

I skoro wiadomo, że w ludzkim ciele odkryto części symetryczne ${ }^{39}$, te jednak w żadnym z ludzi nie są takie w pełni, trzeba zanotować wszelkie odchylenia i zobaczyć, czy da się na ich postawie wyciągnąć jakieś ogólne wnioski o budowie ciała.

I kiedy pisze się historię dziejów na sposób Panów Wrenna i Hooka oraz innych myślicieli, czy, jak często mówiłem, [kiedy] tworzy się kalendarz lat minionych ${ }^{40}$, trzeba dokładnie notować, jakich zmian doświadczyło się w owym czasie. Najlepsze zapiski mogliby tu zrobić zwłaszcza ci, którzy zawsze żyli w ten sam sposób, jak ludzie należący do stanu chłopskiego.

Trzeba przebadać, co dzieje się, gdy określony człowiek cały czas żywi się wodą, wodą i chlebem itp., i jakie korzyści płyną z prostej, jednorodnej, długotrwałej diety.

Ze stanu włosów człowieka można bez wątpienia wyciągnąć różne przydatne wnioski. Że o nosie i innych [częściach ciała] nie wspomnę ${ }^{41}$.

39 Części symetryczne, czyli takie, które a) zachowują właściwe rozmiary i właściwy stosunek wzajemny, b) posiadają własną oś symetrii.

${ }^{40}$ W 1691 r. Leibniz pisał do Lorenza Hertela o konieczności stworzenia kalendarza medycznego. Zob.: G. W. Leibniz, An den Hofrath Hertel, am 9. Juli 1691, [w:] Leibnitz's Deutsche Schriften, hrsg. von G. E. Guhrauer, Bd. 2, Berlin 1840, s. 458 i nast. Por. także: idem, Propozycja utworzenia..., s. 137.

${ }^{41}$ Nawiązanie do fizjonomiki i metoposkopii. Zob. np.: J.-J. Courtine, C. Haroche, Historia twarzy, Gdańsk 2007; J.-J. Courtine, Zwieciadto duszy, [w:] Historia ciata, red. G. Vigarello, t. 1: Od renesansu do oświecenia, Gdańsk 2011, s. 275-282. 
Należy sprawdzić, czy Antimonachale Antimonium crudum ${ }^{42}$ będzie równie dobry dla ludzi jak dla świń i koni, kiedy zacznie się go dawkować stopniowo (łac. cur per gradum).

Między członkami istnieje pewien wzajemny stosunek i komunikacja (łac. consensus und Communicationis), co żywy może poczuć sam na sobie, ale czego w zmarłym się nie znajdzie. Dla przykładu, każdy może odczuć, w jakim związku z głową pozostają genitalia i podeszwy stóp. Lekkie nacieranie podeszew stóp wywoła w głowie określone wrażenia. Podobnie pozostałe znane eksperymenty. I być może zgodne z rozumem jest także to, że członki, które utrzymują względem siebie stałe proporcje, mają względem siebie też więcej sympatii.

Trzeba próbować tworzyć nowe aforyzmy.

Ktoś, kto stworzy nowy, dotychczas nieznany acz akuratny (a przynajmniej bardziej ogólny) aforyzm, powinien otrzymać gwarantowaną nagrodę. Także ten, kto potrafi stworzyć aforyzm zgodny z rozumem, teraz rozumowi znany, a wcześniej nie. Tu zobacz Claudio Compensa ${ }^{43}$, Monsieur de la Chambre ${ }^{44}$, Antimus to jest Honoré Fabr ${ }^{45}$ i inni o Aforyzmach Hipokratesa ${ }^{46}$. Dołącz nowe aforyzmy dodane przez Laurentio Scholza ${ }^{47}$ itp.

42 Antimonium crudum, Antimonii Sulphuretum, Black Sulphuret of Antimony naturalny antymon. Nazwa antymon (anti-monk) została nadana w celu upamiętnienia mnicha, który zaobserwował, że substancja ta jest korzystna dla świń, toteż postanowił dodać ją do posiłków przygotowywanych w konwencie. Niestety, wszyscy bracia zakonni po spożyciu potraw z jej dodatkiem zmarli. W starożytnym Egipcie i Rzymie w celach estetycznych sproszkowany antymon używały zarówno kobiety (jako puder), jak i mężczyźni (aby wybielić opaleniznę na twarzy). W rolnictwie używano go w celu leczenia ubytków w racicach (Antimonium Crudum dla świń) i kopytach (Pulsatilla dla owiec i koni) zwierząt hodowlanych.

43 C. Campensis, Hippocratis aphorismi ex nova Claudii Campensii interpretatione, ejusdem in aphorismos annotationes, quibus illustrantur evidentis-sima Galeni errata, his deinde nexae sunt animadversiones simul cum apologia in Galenum, itemque naturales animadversiones in Aristotelem, nunc primum in lucem editae, Leyden 1579.

${ }^{44}$ M. Cureau de La Chambre, Novae methodi pro explicandis Hippocrate et Aristotele specimen, Paris (1652) 1668.

45 A. Conygius, Pulvis Peruvianus, Rom 1655.

46 C. Campensis, op. cit.

${ }^{47}$ L. Scholz, Aphorismorum medicinalium sectiones octo, Breslau 1589. 
Trzeba także prowadzić badania nad tym, jak potężne są siła wyobraźni i wiara pacjentów ${ }^{48}$. Stąd trzeba dać medykowi do ręki środki i narzędzia, dzięki którym będzie mógł namówić pacjentów do pewnych rzeczy. W szczególności [trzeba] odkryć przez analogię wzajemną wymianę między błonami zewnętrznymi a narządami wewnętrznymi, tak że przez zastosowanie zewnętrzne [pewnych środków] będzie można niebawem uczynić coś wielkiego.

Nie wątpię, że uda się wynaleźć płyny, które po wprowadzeniu strzykawką rozpuszczą kamienie w pęcherzu moczowym, a także zlikwidują $\square^{49}$ podagrę. Jeżeli będzie stosować się i promować tę metodę, wtedy w ciągu dziesięciu lat dokonamy wspólnie rzeczy wielkich.

Pomyśl, gdzie najmocniej czuć tarcie: na podeszwach stóp, skórze głowy itp., zresztą podobnie czuć [tam] ból, gdy się mocno ściska. Stąd też końce nerwów [znajdują się] albo w owym miejscu, albo w jego sąsiedztwie.

Amara $^{50}$ jest dobra przeciw gorączce, ocet przeciw dżumie.

[Trzeba sprawdzić], czy wtedy, gdy w niektórych [ludziach] przeważa jedna ciecz organiczna (łac. humor), to symetria poszczególnych części ciała takich ludzi odbiega od symetrii ogólnej.

Trzeba próbować wstrzykiwać do krwi wszystkie rodzaje płynów.

Nie można zaprzestać prób z transfuzją krwi, przynajmniej na zwierzętach, wszak oto w Anglii słaby koń dzięki świeżej krwi skopa odzyskał siły ${ }^{51}$.

${ }^{48}$ Więcej na temat siły imaginacji jako przedmiotu namysłu medycznego zob.: K. Pękacka-Falkowska, Etiologia moru w świetle pism loimograficznych. Fizjologia timor pestis (rekonesans badawczy), „Sensus Historiae. Studia interdyscyplinarne” 2010, t. 1, s. 91-105 .

$49 \varsubsetneqq-$ tartaryczny, osadowy; nawiązanie do teorii paracelsjańskiej, zgodnie z którą niektóre choroby mają charakter osadowy (tartar - osad winny). Zob. np.: A. Koyré, Paracelcus, [w:] idem, Mistycy, spirytualiści, alchemicy niemieccy XVI wieku, Gdańsk 1995, s. 109.

${ }^{50}$ Amara - piołun. Tinctura amara - wyciąg alkoholowy z bylicy piołunu używany w gorączkach.

${ }^{51}$ Leibniz nawiązuje do eksperymentów z transfuzją krwi, które prowadził francuski matematyk i filozof natury Jean-Baptiste Denis; zob. np.: J.-B. Denis, An extract of the letter of Mr. Denis... touching the transfusion of blood, of April 2, 1667, „Philosophical Transactions of the Royal Society” 1667, vol. 25, s. 453. 
Trzeba przetestować różnego rodzaje kąpiele lecznicze (łac. balnea), gdyż wszystkie kąpiele wchłaniają się trochę przez pory ${ }^{52}$.

Tak samo [dzieje się w przypadku różnego] rodzaju olejków czy maści i dlatego [należy je] umieszczać na skórze głowy albo w innych [częściach] zewnętrznych. Tak samo różne typy powietrza powodują częste zmiany oddechu.

Tak samo różne efekty daje wpuszczanie rozmaitych płynów do odbytu przez lewatywę albo do miejsc intymnych przez wlewkę.

Tak samo można by postępować $\mathrm{z}$ bańkami: stawiałoby się dwie - jedną ledwie nasączoną, która wyciągałaby ciecz z ciała, drugą zaś pełną płynu, który ciało wciągałoby w siebie. Tak samo trochę płynu nanosiłoby się na określony fragment skóry, a następnie stawiałoby się tam bańki (cięte lub zwykłe), aby płyn lepiej się wchłonął przez ciało. Dzięki rozmaitym aplikacjom baniek można najlepiej odczuć współpracę różnych części [ciała ${ }^{53}$. Przy czym można nie tylko wpuszczać płyny do krwi, lecz także opróżniać z niej ciało.

Można dowolnie łagodzić przetaczaną krew dzięki różnym iniekcjom lub uciskom.

W przypadku stwardniałych i zniszczonych żył (jeśli są one naturalnymi przyczynami śmierci) nie ma nic lepszego niż ich rozciagganie i wzmacnianie ich przez określone kąpiele.

[Trzeba] dokładnie opisać historie wszystkich długowiecznych. Dodaj De Longaevis Meyboma ${ }^{54}$.

52 Stąd też Bacon wymagał, aby woda miała taki sam skład jak materia ciała: „pierwsza i podstawowa jakość jest taka, iżby kąpiele składały się z rzeczy o substancjach podobnych do cielesnych i organicznych, które mogłyby utrzymać i odżywić wnętrze” (idem, Historia naturalis, London 1622, s. 392, cyt. za: G. Vigarello, Czystość i brud. Higiena ciata od średniowiecza do XX wieku, Warszawa 1996, s. 20).

${ }^{53}$ Nawiązanie do medycyny hipokratejsko-galenowej i koncepcji sympatii, czyli przyciągania.

${ }^{54} \mathrm{H}$. Meibom (młodszy), Epistolae de longaevis ad serenissimum celsissimumque principem ac dominum Dn. Augustum ducem Brunsvicensem ac Lunaeburgensem octogesimum sextum annum agentem, Helmstedt 1664. Heinrich Meibom (1638-1700) - niemiecki anatom i lekarz. Leibniz utrzymywał z nim osobiste kontakty, np. w liście do Burneta napisał, że w sprawie jego cierpień „zasięgnął rady jednego z najzręczniejszych lekarzy w Niemczech nazwiskiem Meibom”. Por.: K. F. H. Marx, Gottfried Wilhelm Leibniz in 
Tak samo [należy] zanotować wszystkie historie, które były nieco wyjątkowe, przykładowo o apopleksji, epilepsji itp.

Trzeba ustalić stałą liczbę najlepszych potraw i określić formy najlepszych sposobów życia, zgodnie z temperamentem każdego człowieka. A że liczba [typów pożywienia] jest nieskończona, trzeba spróbować zredukować je do kilku. Ponieważ widzimy, że także ludzie starzy i zdrowi chwalą sobie małą liczbę potraw.

Trzeba też znaleźć środki [spożywcze] i określić takie formy [diety], które będą harmonizować ze wszystkimi temperamentami.

Aptekę [należy] ograniczyć do kilku haupt species ${ }^{55}$ zgodnie z zamysłem Daniela Ludoviciego ${ }^{56}$ i później ustanowić po jednej takiej aptece w każdej miejscowości.

Tak jak bartoszkowie ${ }^{57}$ przyjęli prowadzić własne seminaria i parafie, tak i tu trzeba sprawić, by w każdej miejscowości przebywało dwóch ludzi,

Seine Beziehungen zur Artzneywissenschaft, „Abhandlungen der Königlichen Gesellschaft der Wissenschaften zu Göttingen” 1858/1859, Bd. 8, s. 406.

55 Species - wszystkie składniki proste (ingridentia simplicia), z których wykonuje się leki złożone (compositia); nazwa stosowana także w przypadku proszków leczniczych. Por.: Zedler, Bd. 38, s. 648.

${ }^{56}$ D. Ludovici, Archiatri quondam Ducal. Saxo-Goth. Opera Omnia, videlicet I. De Pharmacia moderao Seculo appiicanda Dissertationes in. cum Commentario, Gotha 1671, s. 28-30.

${ }^{57}$ Bartolomici, bartoszkowie - Zgromadzenie Kleryckie Księży Życia Wspólnego (Institutum Clericorum Saecularium in Communi Viventium); zgromadzenie założone przez kanonika salzburskiego ks. Bartłomieja Hozhausera w 1640 r. w Salzburgu. Co interesujące, w jednym z późniejszych listów do Huygensa filozof postulował zbudowanie organizacji medycyny na bazie organizacji zakonu kapucynów. Zob.: G. W. Leibniz, Sämtliche Schriften und Briefe, R. 3: Mathematischer, naturwissenschaftlicher und technischer Briefwelscher, Bd. 6, Nr. 45, Berlin 2004: Leibniz an Christiaan Huygens, Hannover, 12./22. Juni 1694, s. 124 i nast.: „Plût à Dieu, que nos études servissent ànous faire avancer considerablement dans la Medecine. Mais jusqúicy cette science est presque entierement Empirique. Il est vray que l'Empirie même seroit de grand usage, si on sàttachoit à bien observer, et même à bien employer tant d'observations déja faites, mais comme la Medecine est devenue un Mestier, ceux qui en font profession ne la font que par maniere dàcquit, et autant qu'il faut pour sauver les apparences; sçachant bien que peu de gens sont capables de juger de ce qùils font. Je voudrois que quelque ordre religieux, tel que celuy des Capucins par exemple, se fut attaché à la Medecine par un principe de charité. Un tel ordre bien regléla pourroit porter bien loin". 
stary i młody, którzy będą fizykami tudzież medykami i którzy będą często się wymieniać.

Należy nakazać lekarzom brać [pieniądze] nie od pacjentów, a tylko od państwa.

Tak samo należy zakazać medykom przyjmowania jakichkolwiek podarków, w ten bowiem sposób utnie się wszelkie rozważania [na temat tego, komu pomagać,] i każdy człowiek będzie doglądany z tą samą pilnością.

$\mathrm{Z}$ tego powodu [medycy] muszą składać przysięgi.

[Medycy] muszą być utrzymywani przez państwo, zresztą tak jak ich rodziny ${ }^{58}$.

Najlepiej byłoby wtedy, gdyby została wśród nich przyjęta reguła [wspomnianego już] zakonu. Ponieważ zakonnicy są bez-interesowni. Stworzony przez nich zakon byłby najlepszym środkiem do rozwijania chrześcijaństwa, czego trzeba sobie życzyć.

Widać, że tego właśnie matematyka dokonała w Chinach $^{59}$, o wiele więcej dokonają [jednak] medycyna i fizyka, które są niezbędne wszystkim ludziom. Dzięki misjom zgromadzi się wszystkie sekrety (łac. acana) ${ }^{60}$ i simplicia świata.

Medyk ma [mieć] przystęp generalny (łac. adito generale) do wszystkich ludzi - szczególnie wtedy, gdy jest on bez-interesowny.

58 Leibniz proponował, aby wielcy lekarze byli wynagradzani takim salarium jak wielcy generałowie, co doprowadziłoby do osiąnnięcia przez medycynę większej perfekcji. Ponadto wielokrotnie podkreślał konieczność finansowania medycyny ze środków publicznych. Zob. np.: idem, Propozycja utworzenia..., s. 134.

59 Leibniz nawiązuje tu do sukcesów misyjnych jezuitów w Chinach w XVI i XVII w., m.in. do działalności misyjnej ojca Matteo Ricciego. Co interesujące, Leibniz usiłował ustanowić systematyczną współpracę między chińskimi i europejskimi naukowcami, w tym celu nawiązując kontakt z Claudio Filippo Grimaldim, który po Ferdinandzie Verbiestcie objął kierownictwo Biura Astronomicznego w Pekinie. Przy czym, choć filozof uważał Chińczyków i Europejczyków za równych w przypadku badań eksperymentalnych, to jednak dawał pierwszeństwo europejskiej myśli teoretycznej, traktując ją jako bardziej zaawansowaną. Zob. np.: D. F. Lach, Leibniz and China, „Journal of the History of Ideas” 1945, vol. 6, s. 436-551; Cambridge History of Science, vol. 3, s. 827-835; F. Perkins, Leibniz and China. A Commerce of Light, Cambridge 2007.

${ }^{60} \mathrm{~W}$ systemie paracelsjańskim arcanum to ukryta moc lecznicza danego simplicitum. Przykładowo w dzisiejszym dyskursie naukowym arcanum maku byłaby morfina. 
Każda główna ulica albo kwartał ludnego miasta powinny mieć zarówno własnego medyka, jak i pastora. Przy czym powinni działać także superintendenci tudzież superintendenci generalni.

Trzeba urządzić medycynę na wzór Kościoła.

Wymagana będzie także spowiedź, do której ludzie będą wszakże chętnie przystępować.

Jednakże po to, aby spowiedź przebiegała sprawniej, trzeba będzie powszechnie przedłożyć ludziom [odpowiednie] pytania - zupełnie tak, jak gdyby posiadało się książeczkę do spowiedzi, która mówi o tysiącu dających się pomyśleć grzechach, by nie zapomnieć o żadnym.

Trzeba określić dokładne terminy w ciągu roku, w których każdy człowiek będzie mógł odbyć spowiedź medyczną i powiedzieć wszystko [swemu lekarzowi], przy czym pierwej powinno się ustalić czas, jaki zostawi się choremu na zastanowienie i przemyślenia.

Dodatkowo każdy powinien mieć możliwość przystąpienia do spowiedzi nadzwyczajnej.

I tak, jak w Kościele pozwala się na wybór swego spowiednika, który nie jest z probostwa, tak też musi być i tutaj, że ma się wędrownego (łac. vagos) medyka, który nie jest przywiązany do żadnej parafii, i dlatego będzie można wybrać tego, którego się zechce.

I w sytuacjach wyjątkowych spowiednik prywatny będzie komunikował się z ordynaryjnym [tj. ze swym zwierzchnikiem].

Przy spowiedniku ordynaryjnym w spowiedzi generalnej powinno się powtórzyć wszystko to, co wyznało się wcześniej w prywatnej ${ }^{61}$.

Tym, czym w spowiedzi duchowej jest nałożenie pokuty, tym tutaj powinno być przedłożenie zasad, według których należy postępować.

Zatem spowiednicy duchowi powinni mówić nie tylko o zadośćuczynieniu tudzież odkupieniu, lecz także dawać reguły na przyszłość.

Reguły i zadośćuczynienie, o których prawi spowiednik medyczny, nie powinny polegać na [przepisywaniu] recept, lecz na regulacji diety, tak

${ }^{61}$ Kościół luterański uznaje trzy typy spowiedzi: a) codzienną spowiedź w modlitwie przed Bogiem, b) spowiedź indywidualną (prywatna) u pastora, zakończoną absolucją, oraz c) spowiedź powszechną w kościele przed ołtarzem. Inna klasyfikacja spowiedzi to podział na spowiedź zwykłą i generalną (z całego życia). 
jak te, które daje spowiednik duchowy powinny bazować bardziej na przedstawieniu określonych ćwiczeń [duchowych], niż na odmówieniu ustalonej liczby avemaria czy paternoster itp.

Spowiednicy duchowi i medyczni powinni komunikować się ze sobą $_{a}^{62}$, lecz żaden $[\mathrm{z}$ nich] nie powinien ujawniać przed drugim tego, co mogłoby przyczynić się do wywołania uprzedzeń względem pacjenta. W tym, co mogłoby wywołać uprzedzenia względem pacjenta, spowiednik medyczny powinien być tak samo mocno związany zasadą milczenia jak duchowy.

Spowiednicy duchowi powinni zostać zaznajomieni z określonymi narzędziami i pytaniami, dzięki którym uda się odróżniać ludzkie humory, wskutek czego będzie można poznać nie tylko afekty in genere, lecz także dość precyzyjnie określić ich stopnie oraz kombinacje, co następnie niewiarygodnie łatwo posłuży medykom do rozpoznania temperamentu.

Natomiast spowiednik duchowy przez poznanie namiętności mógłby w wielkim stopniu przyczynić się do wytłumaczenia temperamentu.

Uważam za karę bożą, że byliśmy dotąd tak ślepi i nie kierowaliśmy choćby tysięcznej części naszej troski na takie rzeczy podstawowe, i nadal jej nie kierujemy. Mogę w pełni powiedzieć, że martwię się nieomal tak samo - przez analogię - gnuśnościq $q^{63}$ zdrowotną i duchową.

I [martwię się także] tym, że my ludzie z największym nierozsądkiem traktujemy nie tylko naszą duchowość, co zresztą nie jest dziwne, ponieważ nigdy nie widzieliśmy ani świętego ani potępionego, ale i tym, że nie zważamy na zdrowie. Zatem codziennie widzimy, że te same męki, których doświadcza potępieniec w piekle, obecne są już w życiu doczesnym u tych,

${ }^{62}$ Także w innych tekstach Leibniz wskazywał, że poznanie duszy warunkuje poznanie ciała i odwrotnie. Zob. np.: Opuscules et fragments inédits de Leibniz: Extraits des manuscrits de la Bibliothèque royale..., par L. Couturat, Paris 1906, s. 12: „Unde sequitur, nos saepe ex cognitis corporis qualitatibus animae et ex cognitis animae pathematis corpori mederi possi”. Por.: M.-N. Dumas, Leibniz und die Medizin, „Studia Leibnitiana” Sonderheft 7, 1978, s. 150.

${ }^{63}$ Acedia, akedeia - gnuśność, brak troski o własny byt i istnienie, obojętność. W teologii wypalenie religijne, apatia i obojętność, tzw. choroba mnichów, duchowa „depresja”. Za lekarstwo na acedię mnisi uważali dbałość i uważność w wykonywaniu wszystkich czynności, osiąganą dzięki medytacji i kontemplacji. 
którzy bardziej troszczą się o dobra ziemskie niż o własne ciało (że o duszy nie wspomnę).

Konieczne jest, abym zebrał wszelkie napomnienia, zachęty, pouczenia oraz wszystko to, co zostało wymyślone przez pastorów oraz mówców do poruszenia afektów, by w ten sposób przedstawić i uświadomić nam nasz nierozsądek.

Ale mam nadzieję, że będę miał do czynienia z osobami, które wystarczająco [dobrze] pojmują te rzeczy, kiedy opowie się im je ładnie i przy użyciu niewielu słów ${ }^{64}$. I ponadto mam wielką nadzieję, że projekty Towarzystwa Angielskiego w mechanice, jak i instrukcje polityczne, które zostały wydane w pismach nauczycieli, ukażą, że analogiczne [urządzenia] są wysoce konieczne w medycynie.

Trzeba zebrać ze wszystkich miejscowości taksy apteczne, zarządzenia antymorowe i ustawy zdrowotne. Legenda Verulama pomnaża naukę $^{65}$. Historia vitae et mortis ${ }^{66}$, Sanctoriego Methodus vitandorum errorum omnium $^{67} \mathrm{~W}$ medycynie.

[Trzeba sprawdzić,] czy [da się] wprowadzić taką dietę, która znalazłaby uznanie wśród wielu [osób] jednocześnie i która by złączyła kilka [rzeczy] w jednym czasie, na przykład muzykę i zapach, natomiast inne rozłączyła, np. muzykę i sen.

[Trzeba sprawdzić,] czy [da się] stworzyć przyrządy, przy użyciu których będzie można zbadać sposób, w jaki człowiek staje się silniejszym czy słabszym, zob. waga, użycie purgansów itp.

Skoro uważam zmysł smaku za najlepsze narzędzie, które pozwala poznać naturę rzeczy, to trzeba szukać wszelkich sposobów, dzięki którym u pewnych ludzi wykształci się smak w najwyższym stopniu subtelny. Wiadomo, że osoby, które piją wyłącznie wodę, mają tak subtelny smak, że mogą dzięki niemu odróżnić różne typy wody, czego nie potrafią inni.

${ }^{64}$ Nawiązanie do retorycznej zasady rzeczowości i zwięzłości: mało słów, lecz dużo myśli (non multa, sed multum).

${ }_{65}$ F. Bacon, De dignitate et augmentis scientiarum libri IX, London 1623.

${ }^{66}$ Idem, Historia vitae et mortis, sive titulus secundus in Historia naturali et experimentali ad condendam philosophiam, quae est Instaurationis magnae pars tertia, London 1623.

${ }^{67}$ S. Santorio, Methodus Vitandorum Errorum Omnium qui in Arte Medica Contingunt, Venedig 1603. 
Dlatego też trzeba karmić pewne osoby w sposób prosty, np. wodą i chlebem, albo mąką na sposób turecki. Stąd będą mogły one odróżniać rzeczy uważane przez innych ludzi za pozbawione smaku (łac. insipidus), dzięki czemu smaki (łac. sapida) będą rozróżniane dużo dokładniej. Do tego należy także nauka handlarzy win, mówiąca o posiadaniu czystego smaku. Pierwej zawsze trzeba skosztować wodę, nim skosztuje się coś innego.

Kiedy udaje się zharmonizować obserwacje smakowe z określonym przyrządem, jak w przypadku roztworów solnych, wtedy można używać go zamiast [zmysłu] smaku. I tak, gdy wiemy, że wodę posolono, wtedy można określić stopień [jej] zasolenia tylko na podstawie wagi [płynu], bez użycia smaku.

Trzeba utrzymywać w państwie określonych ludzi, którzy mają doskonałe powonienie, określonych ludzi, którzy mają taki dotyk, jak ślepy u Boyle’a. Takie różne typy ludzi są bardziej przydatne niźli różne typy rzemieślników.

Trzeba często publikować książki, które zachęcają ludzi do [studiowania] rzeczy rzeczywistych (łac. ad realia), rozprzestrzeniać je wśród nich w wielu językach, aby można było je czytać. Powinno się nakazać możliwie wcześnie stawiać za wzór dzieciom w szkole np. metodę Vicesa, Bacona, Kartezjusza.

Mają zwyczaj używać do rozweselenia opium tureckie, sądzą bowiem, że nadaje ono kolor twarzy i odświeża umysł ludzi, tak iż ten, kto raz go użyje, zawsze będzie się nim delektować. Sorantius ottomanno p. 2 n. 49 p. $\mathrm{m} 63^{68}$.

$\mathrm{Na}$ podstawie muzyki można rozróżnić [ludzkie] natury i temperamenty; ktoś chętnie słucha tej piosenki, ktoś inny tamtej, i dlatego trzeba by prowadzić skrupulatne obserwacje z tarantulami i z tymi, którzy zostali przez nie pokąsani. Każdy medyk powinien mieć możliwość stale opisywać wszystko, co widzi i słyszy, w szczególności zaś możliwość zapisywania zaobserwowanych przez siebie przyczyn [choroby]. Pogląd ten podstawą swojej nauki uczynił także Hipokrates w Świątyni Eskulapa, która w jego ojczyźnie na wyspie Kos dziś nazywa się Longa. Wyleczone przez niego choroby były w niej rejestrowane, tak jak i środki, dzięki którym je ule-

${ }^{68}$ L. Soranzo, L'Ottomano, bmw, 1600. 
czono. Te Hipokrates nieco skrócił i pozostawił przyszłym [pokoleniom], i tak pozostała jedynie ta wiedza, chociaż świątynia dawno spłonęła, i tylko te nieliczne obserwacje przypadków (łac. particular observationes) stanowią fundament racjonalnej medycyny. Dlaczego staliśmy się zatem tak ślepi, że ich nie studiowaliśmy z większą pilnością i nie wprowadziliśmy ich w życie? W ten sposób w ciągu stu lat nauczylibyśmy się więcej, niż od czasów Hipokratesa do początku tego wieku. Ba, nawet nie w ciągu stu lat, ale dziesięciu.

Wszystkich pacjentów, którzy zmarli w nozokomiach ${ }^{69}$, należy poddać sekcji. [Rozciąć] przynajmniej w miejscu [choroby, która spowodowała] ich śmierć. To, co dla wielkich panów nie jest uciążliwe, nie powinno być uważane za takie przez ludzi gminnych (łac. privati).

To, że śledziona produkuje materię kwaśną albo ostrą, można stwierdzić na przykładzie rocznego dziecka, które ciągle kaszlało, ale nic nie odpluwało. Po otwarciu go po śmierci jego śledziona była za mała, a płuca i wątroba za duże. A zatem materia, która przynależy do śledziony, wydostała się tamtędy.

Trzeba odkryć sposób, w jaki można by wedrzeć się głębiej i głębiej do wnętrza ciała. Dzięki wpuszczaniu klistra - zarówno do odbytu, jak i do gardła - już wynaleziono pewien sposób, tak samo dzięki phlegmagogum $^{70}$ circumforanei ${ }^{71}$, o czym w „Ephemerid. Med.”72. Tak samo dzięki usuwaniu kamieni, przepukliny, katarakty, przywróceniu płynu w oku u Borriego $^{73}$, wreszcie otwieraniu żył i transfuzjom, że o rzeczach wprowadzanych przez żołądek nie wspomnę. Trzeba tylko dalej szukać środka, aby

${ }^{69}$ Nozokomia - przytułki, miejsca opieki nad ubogimi chorymi.

70 Typ śluzopędnych środków przeczyszczających. Pozostałe typy środków przeczyszczających to melanogoga i cholagoga. Por.: Zedler, Bd. 27, s. 1097.

${ }^{71}$ Circumforanei, circulatores - szarlatani, oszuści i inne osoby podróżne, sprzedające leki.

72 „Miscellanea Curiosa Medico-Physica Academia Naturae Curiosorum” - czasopismo medyczne wydawane od $1670 \mathrm{r}$.

${ }^{73}$ G. F. Borri, Epistolae duae, I. de cerebri ortu et usu medico, II. de artificio oculorum humores restituendi, ad. Th. Bartholinum, Kopenhagen 1669, s. 36-68. Giuseppe Francesco Borri (1627-1695) - włoski alchemik i lekarz oraz prorok, zwolennik jatrochemii. 
móc wyciąć [coś] z człowieka, jak to się stało w Cultrivoro ${ }^{74}$. W przypadku tych spraw trzeba wymyślić sposób sprowadzenia na ludzi głębokiego snu - i nic im wówczas nie zaszkodzi, albowiem w jego trakcie niczego nie poczują - z którego będzie można ich łatwo wybudzić, jak wtedy, gdy przykłada się opium szafranowe albo silny zapach. Trzeba także poszukiwać takiej sztuki cięcia, dzięki której przecinać będzie się tylko części łatwo się zabliźnią̧ące, i będzie je można znów wyleczyć, kiedy człowiek się wybudzi, uratowany swoim przyrodzonym ruchem. [Trzeba sprawdzić,] czy da się wynaleźć sposób łatwego oczyszczania żołądka z żółci, jak przez wymioty [prowokowane] według woli, jak przez połykanie czegoś przywiązanego nitką, co następnie umożliwia zwrócenie, jak dzięki piórom, które przecie czyszczą żołądek.

Wszelka choroba ciała bierze swój początek z płynu bądź z materii. Jeżeli z płynu, to z pewnością [pochodzi ona] albo z ducha (łac. spiritus) ${ }^{75}$, albo z krwi. Ducha można utwierdzić zapachem, krew - dzięki infuzjom [wstrzyknięciom], lecz także na inne sposoby. Pożywienie oraz napoje zmniejszają lub zwiększają proporcje między żółcią, śliną, flegmą i sokiem trzustkowym. W płynie albo jest czegoś za dużo, albo za mało; albo ruch w jego obrębie jest niepotrzebny; albo miejsce ruchu jest niewłaściwe; albo niewłaściwy jest ciężar płynu; albo pojawiają się w nim zewnętrzne względem niego dodatki; albo zachodzą jakieś alteracje [tj. zmiany]. Alteracja zachodzi wtedy, kiedy płynu albo jest za dużo i jest on zbyt rzadki, albo gdy jest [on] zbyt gęsty, zbyt ciepły, zbyt zimny itd.; kiedy zmieniają się [jego] kolor, zapach, smak oraz inne [właściwości]. Dlatego koniecznie trzeba skrupulatnie badać określonych ludzi nie tylko ze względu na ich zmysł smaku, lecz przede wszystkim $\mathrm{z}$ uwagi na ich plwocinę; skądinąd $\mathrm{w}$ tym

${ }^{74}$ D. Beckher, De Cultrivoro Prussiaco Observatio \& Curatio Singularis, Koenigsberg 1638, Leyden 1938, s. 78-88. Por. historię o połkniętym nożu, którą opisano w: T. Brown, Pseudoxia Epidemica, London 1672 [adres źródła internetowego: http://penelope.uchicago.edu/pseudodoxia/pseudo23.html\#b8].

${ }^{75}$ Więcej na temat koncepcji ducha/tchnienia (łac. spiritus) we wczesnonowożytnej medycynie zob.: K. Pękacka-Falkowska, Etiologia moru..., s. 98 i nast.; G. Klier, Die drei Geister des Menschen. Die sogenannte Spirituslehre in der Physiologie der Frühen Neuzeit, „Sudhoffs Archiv" 2002, H. 50. 
przypadku każdy człowiek może sam [siebie] badać z najwyższą uwagą ${ }^{76}$. Podobnie ze smaku mleka, krwi itp. da się wyciągnąć niezbite wnioski.

[Trzeba określić,] czym jest niewłaściwa ilość w puchlinie wodnej, tak też w nadmiarze krwi albo w przekrwieniu; [trzeba wskazać także] miejsce niewłaściwe zarówno w wynaczynieniu [tj. ekstrawazacji], jak i w przypadku pleurozy. [Należy] zwróć uwagę, że wiele chorób zbiega się ze sobą albo z jednej powstaje druga, np. ruch powstaje ze zmiany, a zmiana bierze się z ilości albo miejsca. [Analogiczna sytuacja może zachodzić] w ciałach stałych: albo jest w nich czegoś za wiele, albo za mało, albo występują inne ograniczenia; albo substancja jest zbyt delikatna, albo zbyt twarda, zbyt gąbczasta itp;; albo rozciąła, albo zbita, ciężka lub lekka; stąd bierze się ropa, osłabienie, [dany] kolor, zapach, smak - albo pojawia się coś obcego.

Należy ustanowić środki, dzięki którym będzie można zdiagnozować, gdzie leży choroba danego człowieka. Często lekarze nie wierzą osobom, które mówią, jaka część ich ciała jest dotknięta schorzeniem, a prawda wychodzi na jaw poniewczasie [gdy choroba w pełni się rozwinie]. Jednakże czasem dzieje się odwrotnie. Chory nie wskazuje prawdziwego miejsca bólu. Istotnie, ból i dotyk mogą oszukiwać - zresztą tak jak wzrok i słuch - odnośnie do wskazywanego [przez chorego] miejsca. Acz być może jest i tak, że owo oszustwo - charakterystyczne również dla wzroku i słuchu - da się zredukować [wychwytując jego] powody i [rządzące nim] reguły. Stąd też trzeba umożliwić [chorym] snucie domysłów o miejscu dotkniętym chorobą. Zaiste, [po zebraniu i zestawieniu ze sobą] tych wszystkich przemyśleń, sporów i wskazań [miejsca odczuwanego] bólu, da się wykazać [jego] prawdziwą przyczynę.

O ile wiem, Bellini ${ }^{77}$ zaczął matematyzować medycynę, zresztą tak jak i Steno, [natomiast dziś czyni to] niemal każdy.

${ }^{76}$ Zgodnie z teorią humoralną każdy płyn ustrojowy miał jakiś smak. Krew była słodkawa, flegma - mdława, żółć - gorzka, natomiast czarna żółć - kwaśna. Por.: J. Delumeau, Grzech i strach. Poczucie winy w kulturze Zachodu XIII-XVIII w., Warszawa 1994, s. 24.

77 Lorenzo Bellini (1643-1704) - włoski lekarz i fizyk, zwolennik jatromechaniki. Zaproponował m.in. jatrofizyczną wykładnię produkcji moczu w nerkach. Zob. np.: T. M. Brown, Lorenzo Bellini, [w:] Dictionary of Scientific Biography, vol. 1, New York 1970 , s. 592-594. 
Trzeba gromadzić obyczaje [tj. sposoby postępowania] wszystkich ludzi dotyczące tych rzeczy [o których mówiłem]. W trakcie podróży należy zbierać wszystko, co dotyczy medycyny.

Istnieją pewne drobiazgi, które należy pilnie obserwować, [gdyż dzięki nim] będzie można chronić człowieka przez całe jego życie. Na przykład, czytanie i pisania w trakcie stania w podwyższonym miejscu chroni przed katarami głowy, umiarkowany ruch przeciwdziała zapaleniu opłucnej, a częste oddawanie moczu - kamieniom w pęcherzu. Powinno się jeść i pić często, acz zawsze w małych ilościach. Należy unikać picia przed snem. Stąd też Lower pisze w $D e c_{0} d e^{78}$, że nocą powinno się po części rozebrać i nieco ochłodzić, kiedy wstaje się w celu opróżnienia pęcherza, [należy także] trochę poćwiczyć swoje ciało. Powinno się stale łączyć ciepło z zimnem dzięki przebywaniu w chłodnej bryzie. Wszystkie rzeczy, o ile to możliwe, należy [regularnie] zmieniać.

Pierwszym zadaniem, które trzeba zrealizować, jest zebranie wszystkich rad i przemyśleń wielu innych ludzi. W ten oto sposób moje rady i plan [który przedstawiłem] przyczynią się do powstania kolejnych. Istnieje wielka liczba ludzi, którzy mogliby robić takie rzeczy, ale nie zostali do tego przez nikogo wezwani i sami nie czują powołania [aby czynić tak, jak proponuję].

Tłumaczyła i opracowała:
Katarzyna Pękacka-Falkowska
Uniwersytet Medyczny im. K. Marcinkowskiego w Poznaniu
Katedra i Zakład Historii Nauk Medycznych
pekackafalkowska@ump.edu.pl

${ }^{78}$ R. Lower, Tractatus de Corde, item de Motu et Colore Sanguinis et Chyli in eum Transito, London 1669. Richard Lower (1631-1691) - angielski lekarz, zajmujący się przede wszystkim problematyką transfuzji krwi i działaniem układu krwionośnego; wychowanek Thomasa Willisa. 